\title{
Response of Soybeans Grown in an Ultisol to Residual Broadcast and Banded P Fertilizer ${ }^{1,2}$
}

\author{
Reinaldo del Valle, Jr., Richard H. Fox, and M. A. Lugo-López ${ }^{3}$
}

\section{ABSTRACT}

An experiment with soybeans, Glycine max (L.) Merrill, was planted at Cidra, Puerto Rico, on May 23, 1973, on a Torres clay, an Ultisol (Orthoxic Palehumults, clayey, mixed, isohyperthermic). The experiment was one of a series designed to study the relative efficiency of banded $v \mathrm{v}$. broadcast $\mathrm{P}$ and of its residual effects on various successive crops. This was the fourth in the series after two corn and one rice experiments cropped in the same field in the seasons immediately preceding its installation. The identity of the plots was maintained throughout the whole series.

There was no grain response to the broadcast or banded $P$, whether limed or unlimed, which had been applied to the previous crops, although soil analyses by both the Olsen and the Bray No. 2 method indicated deficiency of available P. However, a field-wide grain average of $3698 \mathrm{~kg} / \mathrm{ha}$, equivalent to 55 bu/acre, was obtained. The Bray No. 2 extractable P content had fallen to less than $20 \mathrm{p} / \mathrm{m} 2$ years after applying $359 \mathrm{~kg} / \mathrm{ha}$ or less fertilizer $P$. This yield is almost twice that of the average commercial 1973 U.S. yield and demonstrates the potential for growing soybeans on Ultisols of the humid tropics.

\section{INTRODUCTION}

Soybeans are an extremely important and valuable crop in the United States where over 40 million acres are planted in 30 states. Yields range from 16 to $33 \mathrm{bu} /$ acre with a yearly average for the United States of 22 to $27 \mathrm{bu} / \mathrm{acre}(5)$.

The possibilities of producing soybeans under tropical conditions have been explored only scantily. Tropical areas offer a year-round growing season that might permit more than one crop during a year but also have a wide range of pest and soil fertility problems. The wealth of technology in soybean production readily available in temperate areas must be adapted to the tropical environment. Being a legume, soybeans have the ability to supply part of their $\mathrm{N}$ needs, provided that the right strain of Rhizobium bacteria is present, that the soil has an adequate supply of other essential elements, and that soil pH is not too low.

Soybeans require a relatively high available soil $\mathrm{P}$ content for maximum yield $(1,5)$. Since Ultisols and Oxisols in the humid tropics are, in

${ }^{1}$ Manuscript submitted to Editorial Board October 2, 1975.

${ }^{2}$ Joint contribution from the Department of Agronomy, Cornell University, Ithaca, N.Y., and the Agricultural Experiment Station, University of Puerto Rico, Río Piedras, P.R. This study was part of the investigations supported by USAID under research contract ta-c-1104 entitled: "Soil Fertility in the Humid Tropics."

${ }^{3}$ Assistant Agronomist, Assistant Professor of Soil Science at the Pennsylvania State University, State College, Pa. (formerly with Cornell University), and Professor and Soil Scientist, Agricultural Experiment Station, University of Puerto Rico, Magagüez Campus, Río Piedras, P.R. respectively. 
general, low in available $\mathrm{P}$, the $\mathrm{P}$ fertilization requirements of soybeans in these soils need to be determined in order to attain maximum economic yields in these areas.

The objective of the experiment reported herein was to determine the response of soybeans to banded $\mathrm{P}$ applications and to the residual effects of broadcast and banded $\mathrm{P}$ fertilizer applied to crops during the previous 2 years. This study also offered a good opportunity to widen the available information on the potential for soybean production in the humid tropics.

\section{MATERIALS AND METHODS}

The experimental field was located at Cidra, Puerto Rico, $450 \mathrm{~m}$ above mean sea level. The soil is a Torres clay, one of the Orthoxic Palehumults, clayey, oxidic, isohyperthermic. A soybean experiment was installed in the same plots used for three previous experiments, two with corn and one with rice. The first corn experiment was planted in 1971. The soybean experiment was planted on May 23, 1973. Seeds of the cultivar Hardee were planted at the rate of $100 \mathrm{~kg} / \mathrm{ha}$ ( $1.5 \mathrm{bu} / \mathrm{acre})$ in rows $46 \mathrm{~cm}$ (18 in) apart at a distance of $2.5 \mathrm{~cm}$ ( 1 in) between plants, giving a plant population of approximately 860,000 plants/ha. A randomized block design with five replications was used. Plots were $4.57 \times$ $9.1 \mathrm{~m}$. The experiment was totally replanted on June 29,1973 , due to very poor germination resulting from the low available soil moisture during late May and early June. Prior to replanting, Gramoxone (Paraquat) was applied at the rate of $4.6 \mathrm{l} / \mathrm{ha}$ ( 2 qt/acre) to kill the remaining soybean plants from the first planting. Seeds were planted at a depth of $2 \mathrm{~cm}$ with a 2-row planter. The seeds were inoculated with Nitragin ${ }^{4}$ (soybean inoculant).

On 7 of the 11 treatments compared in the corn and rice experiments, P was broadcast in November 1971. before planting the first corn crop, while $\mathrm{P}$ in the banded treatments was applied to the two corn and the soybean crops at planting ${ }^{5}$ (table 1 ).

For the soybean experiment a blanket fertilizer application of $224 \mathrm{~kg} /$ ha (200 lb/acre), $56 \mathrm{~kg} / \mathrm{ha}$ (50 lb/acre) and $17 \mathrm{~kg} / \mathrm{ha}(15 \mathrm{lb} /$ acre $)$ of $\mathrm{K}, \mathrm{Mg}$ and $\mathrm{Zn}$, respectively, as sulfates was broadcast and plowed in prior to planting. No $\mathrm{N}$ was applied since it was expected that the inoculated soybeans would fix $\mathrm{N}$. Observations were recorded on plant vigor, rooting, and nodulation when the plants were at full-bloom.

\footnotetext{
${ }^{4}$ Trade names are used in this publication solely for the purpose of providing specific information. Mention of a trade name does not constitute a guarantee or warranty of equipment or materials by the Agricultural Experiment Station of the University of Puerto Rico or an endorsement over other equipment or materials not mentioned.

${ }^{5}$ Banded $\mathrm{P}$ treatments were omitted in the third crop with rice.
} 
TABLE 1. - Leaf nutrient composition of soybean plants, variety Hardee, 42 days after planting, August 1973

\begin{tabular}{|c|c|c|c|c|c|c|c|c|c|c|c|c|}
\hline \multirow[b]{2}{*}{$\begin{array}{l}\text { Treatment } \\
\text { No. }\end{array}$} & \multirow[b]{2}{*}{ Lime } & \multicolumn{2}{|c|}{$\mathrm{P}$} & \multicolumn{9}{|c|}{ Content of the indicated element, ${ }^{1}$ dry weight basis } \\
\hline & & $\begin{array}{l}\text { Broadcast in } \\
1971 \text { (resid- } \\
\text { ual) }\end{array}$ & Banded $^{2}$ & $\mathrm{P}$ & $\mathrm{K}$ & $\mathrm{Ca}$ & $\mathrm{Mg}$ & $\mathrm{Mn}$ & $\mathrm{Al}$ & Mo & $\mathrm{Cu}$ & $\mathrm{Zn}$ \\
\hline & & \multicolumn{2}{|c|}{$K g / h a$} & \multicolumn{4}{|c|}{$\%$} & \multicolumn{5}{|c|}{$P / m$} \\
\hline 1 & 0 & 1120 & 0 & 0.40 & 2.67 & 1.04 & 0.49 & 898 & 172 & 1.2 & 16 & 115 \\
\hline 2 & 16.8 ton $/$ ha, $1971^{3}$ & 0 & 0 & .32 & 2.74 & 1.22 & .36 & 355 & 151 & .7 & 22 & 84 \\
\hline 3 & $16.8 \mathrm{ton} / \mathrm{ha}, 1971^{3}$ & 90 & 0 & .34 & 2.73 & 1.17 & .35 & 308 & 137 & .2 & 21 & 78 \\
\hline 4 & $16.8 \mathrm{ton} / \mathrm{ha}, 1971^{3}$ & 179 & 0 & .37 & 2.65 & 1.23 & .39 & 351 & 116 & .4 & 21 & 83 \\
\hline 5 & $16.8 \mathrm{ton} / \mathrm{ha}, 1971^{3}$ & 359 & 0 & .39 & 2.97 & 1.07 & .35 & 317 & 101 & .7 & 18 & 71 \\
\hline 6 & $16.8 \mathrm{ton} / \mathrm{ha}, 1971^{3}$ & 1120 & 0 & .42 & 2.67 & 1.22 & .40 & 338 & 124 & .1 & 17 & 74 \\
\hline 7 & 16.8 ton $/ \mathrm{ha}, 1971^{3}$ & 0 & 22 & .34 & 2.85 & 1.11 & .37 & 308 & 133 & .9 & 18 & 85 \\
\hline 8 & 16.8 ton $/$ ha, $1971^{3}$ & 0 & 45 & .40 & 2.97 & 1.07 & .35 & 360 & 128 & .9 & 19 & 79 \\
\hline 9 & $16.8 \mathrm{ton} / \mathrm{ha}, 1971^{3}$ & 0 & 90 & .46 & 3.29 & 1.13 & .42 & 304 & 122 & .5 & 24 & 74 \\
\hline 10 & 16.8 ton $/$ ha, $1971^{3}$ & 0 & 179 & .43 & 2.87 & 1.13 & .38 & 270 & 124 & .5 & 16 & 61 \\
\hline 11 & 16.8 ton $/ \mathrm{ha}, 1971^{3}$ & 359 & 22 & .39 & 2.80 & 1.16 & .36 & 353 & 116 & .3 & 19 & 74 \\
\hline
\end{tabular}

${ }^{1}$ Small and Ohlorogge sufficiency ranges for soybeans: $\mathrm{P}, 0.26$ to $0.50 \% ; \mathrm{K}, 1.71$ to $2.50 \%$; Ca, 0.36 to $2.00 \% ; \mathrm{Mg}, 0.26$ to $1.00 \%$; $\mathrm{Mn}, 21$ to $100 \mathrm{p} / \mathrm{m}$; Cu, 10 to $30 \mathrm{p} / \mathrm{m} ; \mathrm{Zn}, 21$ to $50 \mathrm{p} / \mathrm{m}$; and Mo, 1.0 to $5 \mathrm{p} / \mathrm{m}(6)$.

2 Banded at planting time.

${ }^{3}$ See note 4 , Table 3. 
One week after germination, Buggeta pellets at the rate of $28 \mathrm{~kg} / \mathrm{ha}$ (25 lb/acre) were applied to control snails and slugs which were causing damage to the stems of the young plants. Weekly sprays consisting of a mixture of Diazinon AG-500 (1.3 l/ha) or Malathion (9.5 l/ha + Dithane M-45 (2.2 kg/ha) were initiated 1 month after planting to control leafworms and prevent fungal diseases. Diazinon and Malathion sprays were alternated weekly to prevent insects from possibly developing resistance to the pesticides. Spraying continued on a weekly basis until the pod-filling stage when twice-a-week applications of Sevin powder, $5 \%$ strength, were initiated to control stink bugs and other insects in the lower branches of the plants.

Weeds were controlled primarily by hand during the first 2 to 3 weeks after the seed were sown. Later, when the crop had closed in, weeds were shaded out by the dense soybean canopy.

The third fully developed trifoliate leaves were sampled at early flowering, 42 days after sowing.

The experiment was harvested on October 24, 1973, 117 days after sowing. Subplots of $1.83 \times 7.62 \mathrm{~m}(6 \times 25 \mathrm{ft})$ were selected from the four middle rows of each plot for yield calculations. Plants were cut with machetes at ground level and threshed. Grain, stalks, and shells were oven dried for yield calculations.

Soil samples (six cores per plot) were taken from the control (treatment 2) and the broadcast $\mathrm{P}$ plots (treatments 1 , and 3 to 6) prior to planting and immediately after harvesting when the experimental area was clean of stover. Samples were taken from the 0 to $15-\mathrm{cm}$ depth. Soil from the first samples was analyzed for $\mathrm{pH}$, available $\mathrm{P}$ and $\mathrm{Mn}$, and exchangeable $\mathrm{K}, \mathrm{Ca}, \mathrm{Mg}$, and $\mathrm{Al}$. Exchangeable $\mathrm{Al}$ was measured in the unlimed plots only. Samples taken after harvesting were analyzed for available P, using both the Bray No. 2 and the Olsen methods, and for $\mathrm{pH}$.

\section{RESULTS AND DISCUSSION}

\section{YIELD and TOTAL P UPTAKE}

A field-wide grain yield average of $3698 \mathrm{~kg} / \mathrm{ha}$ ( $55 \mathrm{bu} / \mathrm{acre}$ ) was obtained with no statistical differences among treatments (table 2). This yield was almost twice that of the average soybean yield in the continental United States in 1973 and demonstrates a potential for growing soybeans in the tropics. Yields exceeding $4036 \mathrm{~kg} / \mathrm{ha}$ have been obtained previously at the Corozal Substation in Puerto Rico with the same cultivar (6).

Applications of $359 \mathrm{~kg} / \mathrm{h}$ a or over of broadcast P in 1971 or $179 \mathrm{~kg} / \mathrm{ha}$ of banded $\mathrm{P}$ to each of three crops (two corn crops and a soybean crop) 
significantly increased stem plus pod yields over that of the check treatment. The quantity of $\mathrm{P}$ absorbed by the soybean plants was not consistently related to the amount or method of $\mathrm{P}$ applied. The only treatments which resulted in significantly more $\mathrm{P}$ uptake than the check were the $1120 \mathrm{~kg} /$ ha broadcast + lime (treatment 6) and the 179 $\mathrm{kg} / \mathrm{ha}$ banded treatments applied to each of the two corn and one soybean experiments. These two treatments absorbed significantly more $P$ than all other treatments except the $359 \mathrm{~kg} /$ ha broadcast and the 3 separate $45 \mathrm{~kg} / \mathrm{ha}$ banded $\mathrm{P}$ treatments.

Adding lime to plots treated with $1120 \mathrm{~kg} / \mathrm{ha}$ broadcast P significantly increased $\mathrm{P}$ uptake by the plants. This increase may have been due

TABLE 2.-Soybean grain and stem and pod yields and total plant P uptake, Torres clay, Cidra, Puerto Rico, Autumn 1973 (kilograms per hectare)

\begin{tabular}{rrrrll}
\hline $\begin{array}{c}\text { Treatment } \\
\text { No. }\end{array}$ & $\begin{array}{c}\text { Broadcast in } \\
\text { 1971 (residual) }\end{array}$ & Banded & $\begin{array}{c}\text { Grain yield } \\
\left(13 \% \mathrm{H}_{2} \mathrm{O}\right)\end{array}$ & Stover yield & Total plant $\mathrm{P}^{1}$ \\
\hline 2 & 0 & 0 & 3680 & $1181 \mathrm{~d}$ & $24.03 \mathrm{c}$ \\
3 & 90 & 0 & 3311 & $1258 \mathrm{abcd}$ & $26.29 \mathrm{bc}$ \\
4 & 179 & 0 & 3577 & $1455 \mathrm{abcd}$ & $24.51 \mathrm{c}$ \\
5 & 359 & 0 & 3645 & $1459 \mathrm{ab}$ & $25.28 \mathrm{bc}$ \\
6 & 1120 & 0 & 4378 & $1547 \mathrm{abc}$ & $32.86 \mathrm{a}$ \\
7 & 0 & 22 & 3475 & $1171 \mathrm{~cd}$ & $24.43 \mathrm{c}$ \\
8 & 0 & 45 & 3830 & $1407 \mathrm{abc}$ & $27.09 \mathrm{bc}$ \\
9 & 0 & 90 & 3499 & $1389 \mathrm{bcd}$ & $22.88 \mathrm{c}$ \\
10 & 0 & 179 & 4229 & $1628 \mathrm{a}$ & $31.43 \mathrm{ab}$ \\
11 & 359 & 22 & 3480 & $1479 \mathrm{ab}$ & $28.49 \mathrm{abc}$ \\
1 & $1120^{2}$ & 0 & 3573 & $1435 \mathrm{abcd}$ & $24.35 \mathrm{c}$ \\
& & Mean & 3698 & 1401 & 26.58 \\
\hline
\end{tabular}

${ }^{1}$ Grain P + Stover P (stalks + shells).

${ }^{2}$ No lime treatment.

${ }^{3}$ Values followed by one or more letters in common do not differ significantly at the $5 \%$ probability level using Duncan's Multiple Range Test.

more to increased growth resulting from decreased Mn toxicity in limed plots than to increased P availability, since available soil P (Bray No. 2) was relatively high and about the same in these two treatments at the beginning of the experiment (table 3). Perhaps significant grain-yield responses to $\mathrm{P}$ were not obtained in spite of supposedly low available $\mathrm{P}$ because of rapid mineralization of organic $\mathrm{P}$ in the soil. Fox et al. (2) reported that sufficient $\mathrm{N}$ was mineralized in an adjacent site where there was no response by corn to $\mathrm{N}$ in two successive trials in 1971-72. Further field and greenhouse experiments would be necessary to clarify the response of crops to $\mathrm{P}$ fertilization of this soil.

\section{SOIL NUTRIENT STATUS}

Results of selected chemical analyses of the soils taken prior to planting are shown in table 3 . In the unlimed plots $\mathrm{pH}$ was 3.89 while 
the mean value of all the limed plots was 4.97. Mn extracted with unbuffered $1 \mathrm{~N} \mathrm{KCl}$ was three times higher in the unlimed plots than in all other plots. The Bray No. 2 extractable P contents were not correlated with the amount of $\mathrm{P}$ applied in 1971, but the highest level of $\mathrm{P}$ applied $(1120 \mathrm{~kg} / \mathrm{ha})$ resulted in four to five times more extractable $\mathbf{P}$ than for the other P levels.

Samples taken after the soybeans were harvested showed a $\mathrm{pH}$ of 4.43 in the unlimed plots (table 3) with a mean value for all the limed plots of 5.20. The quantity of $\mathrm{P}$ applied in 1971 was fairly well reflected in the Bray No. 2 and the Olsen P analyses. The amount of P extracted by the

TABLE 3.-Selected chemical properties of soil samples taken prior to planting and after harvesting soybeans from several treatments at the $P$ experiment, Torres clay, Cidra

\begin{tabular}{|c|c|c|c|c|c|c|c|c|c|c|c|c|}
\hline \multirow{3}{*}{$\begin{array}{l}\text { Treat- } \\
\text { ment } \\
\text { No. }\end{array}$} & \multirow{3}{*}{ Lime } & \multirow{3}{*}{$\mathrm{P}^{1}$} & \multirow{3}{*}{$\mathrm{pH}$} & \multicolumn{6}{|c|}{ Prior to Planting } & \multicolumn{3}{|c|}{ After Harvesting } \\
\hline & & & & \multirow{3}{*}{$\mathrm{Ca}$} & \multicolumn{4}{|c|}{ Exchangeable ${ }^{2}$} & \multirow[b]{2}{*}{$\mathrm{P}^{4}$} & \multirow[b]{2}{*}{$\mathrm{pH}$} & \multirow{2}{*}{$\begin{array}{c}\text { Bray } \\
\text { No. } \\
2\end{array}$} & \multirow{2}{*}{$\begin{array}{c}\text { P Ol- } \\
\text { sen }\end{array}$} \\
\hline & & & & & $\mathrm{Mg}$ & K & $\mathrm{Al}$ & $\mathrm{Mn}^{3}$ & & & & \\
\hline & $\begin{array}{l}\text { Metric } \\
\text { ton/ha }\end{array}$ & Kg/ha & & & \multicolumn{3}{|c|}{ Meq/100g } & \multicolumn{3}{|c|}{$P / m$} & \multicolumn{2}{|c|}{$P / m$} \\
\hline 1 & 0 & 1120 & 3.89 & 2.86 & .63 & .45 & 2.75 & 7.4 & 86 & 4.43 & 55 & 33 \\
\hline 2 & $16.8^{5}$ & 0 & 5.00 & 5.82 & .54 & .56 & - & 2.7 & 13 & 5.25 & 7 & 14 \\
\hline 3 & $16.8^{5}$ & 90 & 5.03 & 6.42 & .82 & .50 & - & 2.2 & 17 & 5.21 & 7 & 13 \\
\hline 4 & $16.8^{5}$ & 179 & 4.84 & 5.97 & .55 & .48 & - & 1.9 & 13 & 5.16 & 11 & 20 \\
\hline 5 & $16.8^{5}$ & 359 & 5.08 & 6.42 & .93 & .51 & - & 2.7 & 21 & 5.18 & 12 & 24 \\
\hline 6 & $16.8^{5}$ & 1120 & 4.92 & 6.42 & .60 & .46 & - & 2.6 & 96 & 5.18 & 57 & 46 \\
\hline
\end{tabular}

1 Broadcast in 1971 (residual).

${ }^{2} \mathrm{Ca}, \mathrm{Mg}+\mathrm{K}$ determined with $1 \mathrm{~N} \mathrm{NH}_{4} \mathrm{OAc}, \mathrm{pH} 7.0$, with unbuffered $1 \mathrm{~N} \mathrm{KCl}$, (overnight extraction), $\mathrm{pH}$ in 1 soil: $2 \mathrm{H}_{2} \mathrm{O}$ suspension.

${ }^{3} \mathrm{Mn}^{+}$determined with unbuffered $1 \mathrm{~N} \mathrm{KCl}$.

4 Bray No. 2.

$\therefore$ A total of 16.8 metric tons/ha (7 $1 / 2$ tons/acre) of ground $\mathrm{CaCO}_{3}$ had been applied prior to planting the soybean experiment; 7.8 tons before planting the first corn crop (1971) and 9 tons after harvesting the first corn experiment (1972).

Bray No. 2 dropped about $40 \%$ during the growth of the crop. All but the treatments with $1120 \mathrm{~kg} / \mathrm{ha} \mathrm{P}$ were below $20 \mathrm{p} / \mathrm{m}$, which is considered low for Alabama soils. ${ }^{6}$

It is interesting to note that, after only 2 years in which four crops were grown, the residual effects of $359 \mathrm{~kg} / \mathrm{ha} \mathrm{P}\left(736 \mathrm{lb} /\right.$ acre $\left.\mathrm{P}_{2} \mathrm{O}_{5}\right)$ raised the extractable P levels only a few parts per million.

\section{LEAF NUTRIENT LEVELS}

Less than a month after planting, all the plants from the no lime, high P treatment plots (No. 1) exhibited chlorotic spots in the first fully developed trifoliate leaves. Some of the upper leaves in smaller plants

\footnotetext{
${ }^{6}$ Pearson, R. W., Personal communication, Auburn University, Auburn, Alabama, 1975.
} 
were also crinkled, arousing suspicion of a Mn toxicity. At a more advanced growth stage, the upper leaves appeared to be distorted in shape, crinkled, with marginal cupping and necrotic spots. The affected plots could be easily recognized from a distance. However, it soon became apparent that plant height was not affected by this condition.

Results from spectrographic analyses of leaves taken at the early flowering stage, revealed a mean Mn content of $898 \mathrm{p} / \mathrm{m}$ for the unlimed plots (table 1). This is within the toxic range for soybeans $(3,4,7)$ and confirmed the visual Mn toxicity symptoms. On the other hand, Al leaf levels in this no lime treatment were below the $200 \mathrm{p} / \mathrm{m}$ toxic level (2). It appears, from data in tables 1 and 2, that there was sufficient $\mathrm{P}$ for soybeans even in the zero P plots (treatment No. 2). Adequate P levels reported by the Ohio Plant Analysis Laboratory range from 0.26 to $0.50 \% \mathrm{P}(3)$.

In general, Mo content in the leaves was very low and, hence, probably deficient. An examination of several plants when they were in fullbloom, revealed a nearly complete absence of root nodules. However, the vigorous plant growth and dark green color indicated that the plants were not $\mathrm{N}$ deficient. The soil in this site had a very high $\mathrm{N}$ supplying power (2) and it is probable that this limited nodule formation.

Except for the high Mn in the unlimed plots, low Mo, and perhaps high $\mathrm{Zn}$, the conditions prevailing at the experimental area were apparently suitable for good growth of soybeans.

\section{RESUMEN}

En este trabajo se informa sobre un estudio realizado para explorar cómo responden las soyas a aplicaciones de fósforo en los Ultisols. Este estudio es parte de una serie de experimentos diseñados para explorar la eficiencia de aplicaciones de fósforo en franjas y al voleo y su efecto residual en varias cosechas en sucesión. El experimento fue el cuarto de una serie iniciada en el año 1971 que incluyó 2 siembras sucesivas de maíz y una de arroz, sembradas en la misma área experimental en las épocas que precedieron inmediatamente a su instalación. La identidad de las parcelas experimentales se mantuvo a través de todos los experimentos en la serie. Se utilizó un diseño de bloques distribuidos al azar con 11 tratamientos y 5 repeticiones. Los tratamientos fueron como sigue: sin encalar; $\mathrm{P}$ al voleo, a razón de $1120 \mathrm{~kg} / \mathrm{ha}$.; encalado para llevar el pH a 5.5-6.0 pero sin $\mathrm{P}$; encalado y $\mathrm{P}$ al voleo, a razón de $90,179,359$ y $1120 \mathrm{~kg} / \mathrm{ha}$; encalado y $\mathrm{P}$ aplicado en franjas al momento de sembrar, a razón de $22,45,90$ y $179 \mathrm{~kg} / \mathrm{ha}$; y un último tratamiento en el que se encaló y se aplicaron $359 \mathrm{~kg} / \mathrm{ha}$. de $\mathrm{P}$ al voleo y $22 \mathrm{~kg} / \mathrm{ha}$. de $\mathrm{P}$ en franjas.

Se tomaron muestras del suelo a $0-15 \mathrm{~cm}$. de profundidad antes de la siembra y después de la cosecha, en las parcelas que recibieron los tratamientos 1 al 6 (control y sólo aplicaciones de $\mathrm{P}$ al voleo). Antes de la siembra, el pH medio en las parcelas que no se encalaron fue de 3.89 mientras que en las encaladas subió a 4.97. Los niveles de Mn fueron altos en las parcelas que no se encalaron. El nivel de P, según el método Bray Núm. 2, fue alto en el caso de los tratamientos 1 y 6 , que recibieron $1120 \mathrm{~kg} / \mathrm{ha}$. de P. El resultado de los análisis en las muestras tomadas después de la cosecha reveló un pH medio en las parcelas que no se encalaron de 4.43 mientras que en las encaladas subió a 5.20. Los niveles de P, según los métodos de Bray Núm. 2 y Olsen, fueron altos en las parcelas que recibieron la cantidad más alta de P, (1120 kg./ha.), bien encaladas o sin encalar, como en el caso de las muestras tomadas antes de sembrar. Los resultados de los análisis de las muestras de hojas sugieren que, excepto por niveles altos de Mn, 
relativamente bajos en Mo y altos en $\mathrm{Zn}$, las condiciones prevalecientes en el área experimental eran apropiadas para la producción de soyas.

La soya no respondió significativamente a las aplicaciones de $\mathrm{P}$ en cuanto a rendimiento a absorción de $\mathrm{P}$ a pesar de que el análisis de suelo por los métodos de Olsen y Bray Núm. 2 reflejaron contenidos insuficientes de P asimilable. Los rendimientos de grano fueron muy buenos con poca variación entre los tratamientos. Se obtuvo, como promedio general del campo, un rendimiento de $3698 \mathrm{~kg}$./ha., equivalente a 55 fanegas por acre. Este rendimiento casi duplica el rendimiento medio que se obtuvo en los Estados Unidos continentales en 1973. Rendimientos de tal magnitud demuestran el potencial que existe para la producción de soyas en los Ultisols de los trópicos húmedos.

\section{LITERATURE CITED}

1. Eberhart, S. A., Soybeans. In Guide for Field Crops in the Tropics and Subtropics, Samuel C. Litzenberger, ed., Agr. Tech. Assistance Bur,, Agency Int. Develop. Washington, D.C., 1974.

2. Fox, R. H., Talleyrand, H., and Bouldin, D. R., Nitrogen fertilization of corn and sorghum grown in Oxisols and Ultisols in Puerto Rico, Agron. J. 66: 534-540, 1974.

3. Jones, J. Benton, Jr., Interpretation of plant analysis for several agronomic crops. In Soil Testing and Plant Analysis, Part II, G. W. Hardy et al., Soil Sci. Soc. Amer., Special Publication No. 2, p. 55, 1967.

4. Parker, M. B., Harris, H. B., Morris, H. D., and Perkins, H. F., Manganese toxicity of soybeans as related to soil and fertility treatments, Agron. J. 61: 515-18, 1969.

5. Scott, W. O., and Aldrich, S. R., Modern Soybean Production, S. and A. Publications, Champaign, Ill., 1970.

6. Silva, S., Vicente-Chandler, J., Abruña, F., and Rodríguez, A. J., Effect of season and plant spacing on yields of intensively managed soybeans under tropical conditions, J. Agr. Univ. P.R. 56(4): 365-9, 1972.

7. Small, H. G., and Ohlrogge, A. J., Plant analysis as an aid in fertilizing soybeans and peanuts. In Soil Testing and Plant Analysis, rev. ed., L. M. Walsh and J. D. Beaton, ed., Soil Sci. Soc. Amer., p. 317, 1973. 